\title{
Evaluation of the Relationship between Assets Growth Rate and Financial Performance of Manufacturing Firms in Nigeria
}

\author{
Oliver Ike Inyiama $^{1}$, Ugbor $^{1}$, Raphael Oluchukwu ${ }^{1}$, Chukwuani Victoria Nnenna ${ }^{1}$ \\ ${ }^{1}$ Department of Accountancy Enugu State University of Science and Technology, Enugu State, Nigeria \\ *Corresponding Author: Oliver Ike Inyiama*, Department of Accountancy Enugu State University of \\ Science and Technology, Enugu State, Nigeria
}

\begin{abstract}
This study is to evaluate the relationship between assets growth rate and financial performance of manufacturing firms in Nigeria. Six (6) firms were selected from the twenty two (22) manufacturing firms listed on the Nigeria Stock Exchange Market (NSE) and secondary data collected from the firms for ten years period (2006 - 2015). The data were analyzed using Pearson Product Moment Correlation Matrix and Multiple Regression whereby the effects of the independent variables on the dependent variable were tested. Non-current assets growth rate, current assets growth rate and net assets growth rate were used as proxies for firm growth (independent variables) while profit after tax was used as proxy for financial performance (dependent variable). Result shows that non-current assets growth rate and net assets growth rate of manufacturing firms in Nigeria positively and strongly related with the profit after tax of the firms for the period of 2006 - 2015, while current assets growth rate positively and weakly related with the profit after tax of the firms for the period. The implication is that profit after tax grows as the non-current asset base of the firms grows. It was recommended that manufacturing firms in Nigeria should increase their non-current assets and net assets value by increasing their total assets and reducing the components of their current liabilities; also that the firms should increase their current assets, but should keep it at an optimum level that will ensure that maturing short-term business obligations are met to avoid keeping excess idle funds.
\end{abstract}

Keywords: Assets, Growth, Rate, Financial Performance, Correlation, Regression.

\section{INTRODUCTION}

Financing of business involves planning, acquisition and administration of funds employed in operating the business. Decisions involving the best sources of funds and how they should be used are part of the key functions of firm Managers. Cheong (2009) opined that debt and equity financing are the two financing options most commonly pursued by companies. While debt financing refers to borrowing funds which must be repaid, plus interest, equity financing refers to raising funds by selling shareholding interests in the company. Whichever way the fund is obtained, it must be converted into assets which will in turn generate future benefit to the firm. Manufacturing firms need to acquire raw materials, enough to keep the production line running until the finished goods produced are turned into cash and/or debts, and then inventories replenished. Firms also need to grow their assets by increasing the amount of assets at its disposal and also by adopting new technologies in order to be competitive so as to increase the future flow of benefits to the firms.

Peterson (2002) simply defined assets as those things we purchase today that will bring future benefits. United States Financial Accounting Standards Board Concepts Statement 6, defined assets as "probable future economic benefits obtained or controlled by a particular entity as a result of past transactions or events." Also The United States Institute of Management Accountants defined assets as "any owned physical object (tangible) or right (intangible) having economic value to its owners; an item or source of wealth with continuing benefits for future periods, expressed, for accounting purposes, in terms of its cost, or other value, such as current replacement cost.

One way of classifying assets is based on their ease of convertibility into cash. According to this classification, total assets are classified either into current assets or non-current assets (fixed assets). Other classifications are physical existence (tangible or intangible assets) and usage (operating and non-operating assets). In this study, classification based on convertibility will be adopted. In order to maintain its activity, firms typically need these two types of assets, fixed assets and current assets. 
Fixed assets which include, building, plant, machinery, furniture, and fitting among others are not purchased for the purpose of resale, but for operational purposes (Singh and Pandey, 2008); while, current assets like cash/bank balance, inventory and receivables are seen as key components of the firm `s total assets. A firm may be able to reduce its investment on fixed assets by leasing, but it is practically difficult to do so for current asset (Afza and Nazir 2008). Whatever way assets is defined, it is important to stress that assets must be managed, not just purchased, used up, and replaced.

\section{REVIEW OF RELATED LITERATURE}

\subsection{The Concept of Firm Growth}

Pass, Lowes and Davies (2005) defined firm growth as the expansion of size of firm over time. According to them, firm growth involves growth of assets, or capital employed, turnover, profit and number of employees. Similar to this definition is that of (Kouser, Bano, Azeem and Hassan, 2012), who defined firm growth as an increase in sales of the company, increase in assets size, increase in volume of production, increase in the number of employees, growth of the profits, expansion of business through acquisition or merger, product development and business expansion and diversification. Also the Classical Economics School of Thought lead by Adam Smith, David Ricardo, Thomas Malthus and John Stuart Mill defined firm growth simply as the change between one equilibrium point and another. Kruger (2004) stated that firm growth has various connotations. According to him, it can be defined in terms of revenue generation, value addition and expansion in terms of volume of the business. It can also be measured in the form of qualitative features like market position, quality of product and goodwill of the customers.

\subsubsection{The Concept of Fixed Assets Growth}

Fixed assets otherwise known as non-current assets are those assets that cannot be converted into cash during a year of running a business (Scott, 2003). It includes the land, buildings, furniture and fitting, computers, equipment of manufacturing and other assets which can last for longer periods of time. Fixed assets or non-current assets are more revenue generators than the current assets but the risk involvement is more than in the current assets as it is difficult to convert them into cash and also the involves huge initial capital outlay.

\subsubsection{The Concept of Current Assets Growth}

Assets that can be converted into cash during the normal production cycle are current assets. A normal production cycle is one year, that is, twelve months. Current physical assets are sometimes referred to as convertible assets. These are physical assets such as stock of raw materials, tock of work-inprogress, stock of finished goods, and goods held for resale. Current assets in one business may be a fixed asset in another business. An example of such asset would be real estate held in inventory by a real estate investment firms and sales organization or builder, the same real estate would be a fixed asset for other firm that procure it for use in a production line. Also computers that are manufactured for sale are current assets in the books of the computer manufacturing firms, the same computers are fixed assets in the books of other firms that procure them for use in their production line.

Chan, Karceski, Lakonishok, and Sougiannis (2008) states that net operating assets generally make up a substantial portion of arms' total assets and that these accounts share much common variation. Secondly, asset growth can take a variety of forms (growth in cash, current assets, or long-term assets). Previous work has not generally distinguished between different forms of asset growth and their effects on stock prices. At the very least, one potentially important distinction is between internally generated expansion in assets ("organic" growth) and acquisitions of other companies and their assets. Schlingemann and Stulz (2005), states that acquiring firms over experience leads to disappoint in stock returns.

\subsubsection{The Concept Net Assets Growth}

Net assets are calculated as total assets less total current liabilities. Therefore, net assets value of a company is equal to the equity of the company or the shareholder's fund, when there are no non current liabilities. On the Statement of Financial Position, values of assets are usually reported at historical costs, less accumulated depreciation and impairment costs (if any). In some cases, the difference between historical cost and current market values are very high. On the contrary column, 
all the liabilities are reflected at the market value. The origin of this discrepancy between the historic cost and current market value related to Generally Accepted Accounting Standards (GAAP) which requires that the assets, liabilities and net worth values of a company are computed on historical costs. This implies that the calculated net asset value amount will not reflect the true value of the shareholder's equity or net assets value. Thus, in order to calculate the exact value of net assets it will be necessary to ascertain the current market value of assets of the company. This will only be necessary during merger or acquisition or upon liquidation of the firm (Farkoosh, Farkoosh and Naseri, 2012). For the purpose of this study, however, the historic cost of assets was used in arriving at the net assets or shareholder's funds.

Fairfield, Whisenant and Yohn (2003) disaggregated growth in net operating assets into accruals and growth in long-term operating assets. They found that both components of growth in net operating assets are negatively associated with one-year-ahead return on assets. Whether growth is in current or long-term net operating assets it has been found that the market's apparent mispricing of accruals relates to investors inability to correctly assess the implications of growth in net operating assets for future profitability. Fairfield et al. (2003) argue that net operating assets growth captures the effect of diminishing marginal returns from investment growth (Stigler 1963), thus negatively effecting future profitability. They show that the market fails to understand the negative implications of net operating assets growth for future profitability in a timely fashion. Abnormal negative returns are earned in subsequent periods when the market learns of the negative implications. While both the total assets and the net operating assets growth anomalies have been investigated separately in great depth, no study has systemically examined the relation between these two phenomena.

\subsubsection{Financial Performance}

Various authors define performance in various ways, for instance, Watkins (2007) defined performance as valuable results, accomplishment, or contributions of an individual or an organization, regardless of preferred or mandated process. Ramiz and Junrui (2014) defined performance as an achievement of tangible, specific, measurable, worthwhile and personally meaningful goals. Performance is the ability of an organization to gain and manage the resources in several difference ways to develop a competitive advantage. Literature usually distinguishes between two types of performance, financial or economic performance and innovative performance. This study concentrated on financial performance.

Bhunia, Mukhuti and Roy (2011) defined financial performance as firm's overall financial health over a given period of time. Financial performance of a firm for a period can be ascertained through the process of financial performance analysis. Eshna (2012), states that financial performance analysis is the process of measuring the results of a firm's policies and operations in monetary terms. Also Bhunia et al (2011) affirmed that financial performance analysis is the process of determining the operating and financial characteristics of a firm from accounting and financial statements and that the analyst attempts to measure the firm's liquidity, profitability and other indicators that the business is conducted in a rational and normal way; ensuring enough returns to the shareholders to maintain at least its market value.

Financial analysis involves the use of financial statements. A financial statement is a collection of data that is organized according to logical and consistent accounting procedures. Its purpose is to convey an understanding of some financial aspects of a business firm. It may show a position of a period of time as in the case of a Statement of Financial Position, or may reveal a series of activities over a given period of time, as in the case of an Income Statement. Thus, the term 'financial statements' usually refers to two basic statements: the Statement of Financial Position and the income statement (including notes attached thereto).

\subsubsection{Profit After Tax (PAT)}

Profit after tax can be fully retained by a company to be used in the business or distributed as dividends, if declared and to the share holders. The profit after-tax figure is considered the best measure of the ability of an entity to generate a return, since it incorporates both operating income and income from other sources, such as interest income. Profit after tax is a measure of how competent a company is with regards to converting its revenue into profits, it is also used in margin analysis to 
compare companies within the same industry. According to Aldridge (2015), it helps investors determine how much a company actually earns and can also help determine whether a company needs to control its costs. The profit after-tax margin is closely watched by investors to see if the incomegenerating ability of a firm is changing over time. If so, this could be considered a valuation indicator that may result in a change in the stock price.

\subsection{Theoretical Framework}

\subsubsection{Alchian (1950) Growth of the Fitter Theory}

It is on this theory that the researcher anchors this research because of the strong relationship existing between firm growth and firm profitability.

Growth of the Fitter theory was propounded by Alchian (1950). According to this theory, fitness is depicted by the firm profit, and the profitable firms grow and survive in the market while the other firms exit due to poor performance (Kouser et al., 2012). Alchian (1950) theoretical study argued that fitter firms grow and survive, but less vigorous firms lose their market share and exit through the evolutionary selection mechanism. Thus, if profit rates reflect the degree of fitness, it is possible to predict that profitable firms will grow (Jang and Park, 2011). Delmar et al. (2003) suggests that more profitable firms may have higher potential to grow, since they have already shown a greater fit with the environment and may be able to fund future competitive actions with their own cash flow.

Profitability limits the risk related to acquiring and relying on external resources of financing but also displays a satisfactory level of market demand. Mukhopadhyay and AmirKhalkhali (2010) posit that profit provides the funds for growth. A firm can grow internally through investments in development projects in various ways. It can take advantage of technological opportunities to grow through research and development, leading to product and process innovations. Empirically, firm growth and profitability both are of great concern for the organization but there is still no generalized relationship between them. Many researchers find evidence that profitability has a positive effect on firm growth (Goddard et al., 2004; Coad, 2007, 2010; Davidsson et al., 2009; Serrasqueiro, 2009; Bottazzi et al., 2010; Jang and Park, 2011; Mudambi and Swift, 2011; Kouser et al., 2012; Delmar et al., 2003), while the other studies (Hoy et al., 1992; Reid, 1995) find that profitability is negatively affected by growth.

Olatunji and Adegbite (2014) examined the effect of investment in fixed assets on profitability of selected Nigerian banks. They also analyzed the significant components of fixed assets investment of selected Nigerian Commercial Banks. Data were obtained from annual reports and accounts of selected Nigerian Commercial Banks. Pearson product moment correlation and multiple regressions were employed to analyze the relationship between the dependent variable (Net profit) and independent variables (Building, Land, Leasehold Premises, Fixtures and Fitting, and Investment in Computers.). Results show that there is a significant relationship between Net profit and building, information communication and technology, machinery, leasehold, land and fixture and fitting with the adjusted R2 @ 96\%. Therefore, investments in fixed assets have strong and positive statistical impact on the profitability of banking sector in Nigeria. In order to improve bank profitability through efficient management of fixed assets, Nigerian banks should increase fixed assets investments in form of ICT. Fixed assets utilization and productivity needs to be monitored to boost profitability for shareholders' satisfaction.

Okwo, Ugwunta and Nweze (2012) studied the impact of investment in fixed assets on profitability using firms in Nigerian Brewery Industry. A cross sectional data were gathered from the annual reports of a sample of four firms from the industry for a period of 1995 to 2009. The four firms that constitute the sample were those quoted on the Nigerian Stock Exchange and their inclusion in the analysis was based on availability of data for the sample period. The firms that constitute the sample were, Nigerian Breweries Plc, Guinness Nigeria Plc, International Breweries Plc and Champion Breweries Plc. The result of the test of hypothesis shows that the level of investment in fixed assets does not strongly and significantly impact on the level of reported profit of Breweries in Nigeria.

Chen, Yao and Zhang (2008) examined the effect of corporate asset growth on stock returns using data on nine equity markets in the Pacific-Basin region including Japan (a well-developed economy), China (one of the most rapid growing economies), as well as Hong Kong, Taiwan, Korea, Malaysia, 
Singapore, Thailand, and Indonesia. The data were collected from two sources, stock return and accounting data from the Pacific Basin Capital Market Research (PACAP) databases (available via Wharton Research Data Services). The Japanese market has the longest sample period from 1981 to 2004 while the Indonesian stock market has the shortest period from 1990 to 1998. Fama-French (1993) three-factor model was adopted to compute alphas for decile portfolios. Fama-MacBeth regression was also used to jointly examine the impacts of alternative factors on asset growth effects. Result shows a pervasive asset growth effect in the PACAP markets during the sample period from 1981 to 2004. That is, there is a significantly negative relation between firms' asset growth and subsequent stock returns, suggesting potential inefficiencies of the region's financial systems in allocating capitals and valuing investment opportunities.

Deloof (2003) explored the relationship between profit ratios and asset management of firms in Belgium. Data were collected from a sample of 1,000 Belgium firms listed on the stock exchange for some period of time. The collected data were analyzed using multiple regression analysis. An indirect relationship was detected between the profit ratios and the asset management of all the firms based in Belgium.

Duru (2014) examined the impact of working capital management on the profitability of Nigerian quoted Manufacturing firms. Data were sourced from a sample of 22 manufacturing firms for the period 2000-2011. Generalized least square multiple regressions were used to test the five Hypotheses formulated for the study. Results show that, accounts payable ratio had negative relationship with the industries' profitability. On the other hand, accounts Receivable ratio had positive and significant relationship with profitability. Stock turnover ratio had negative and significant relationship with profitability. Results also show that firm's cash conversion cycle had positive but non-significant relationship with profitability, and Liquidity ratio had negative relationship with profitability. Recommendations were that, there should be a balance between liquidity and profitability; that firms should avoid stock-outs because of the huge sales they made during the years; that firms are encouraged to reduce their cost of sales to make more profit; that firms should also increase their credit sales so as to have enough cash to settle their obligations; and that specialized persons should be hired by these companies for advice on working capital management.

Mathuva (2009) studied the impact of working capital management on the performance in Kenya. Data were collected from a sample of 30 firms listed in Nairobi Stock Exchange for a period of sixteen years (1993 to 2008). Fixed effect regression model of data analysis was used to analyze the collected data. Direct relationship was detected between the time taken to collect cash from customers and the firm's profitability. This implies that firms that make more profits take less time to collect cash from their customers when compared to less profitable firms that take longer time to collect cash from their customers. Also a positive relationship was detected between the time when inventories were brought in and sold and profitability.

Azam and Haider (2011) investigated the impact of working Capital Management on firms' performance for non-financial institutions listed in Karachi Stock Exchange (KSE30). A panel data was collected from 21 non-financial firms listed in Karachi Stock Exchange for a period of 10 years (2001 to 2010). Canonical Correlation statistical tool was used to analyze the collected data so as to ascertain the relationship between working capital management and firm's performance. Result shows that working capital management has significant impact on firms' performance and it is concluded that managers can increase value of share holder and return on asset by reducing their inventory size, cash conversion cycle and net trading cycle. Increase in liquidity and time period to supplier will also lead to firms' overall performances.

Ogundipe, Ogundipe and Ajao (2012) studied cash holdings and firms characteristics using Nigeria emerging markets as evidence. Data for a period of 1995 to 2010 were collected from a sample of 54 Nigeria firms listed on the Nigeria Stock Exchange (NSE). The data were analyzed using correlation coefficient. Result shows that cash flow, net working capital, leverage, profitability and investment in capital expenditure significantly affects the corporate cash holdings in Nigeria.

Farkoosh, Farkoosh \& Naseri ((2012) examined the effect of net assets value in purchasing the shares of investment companies in Iran. The dependent variable is the decision of investors in companies that 
listed on capital markets in Tehran. The independent variable is the net asset value and other factor. A sample of 500 respondents was selected from a population of 2000. Primary data collection method was adopted whereby questionnaires were administered to the 500 respondents out of which 464 of them responded. Standard deviation was determined by using the SPSS software and Excel. The relationships between variables were investigated at various levels using Excel software, SPSS software, demographic Kruskal-Wallis tests as well as Friedman test. Result shows that net asset value with 12.91 points and interest rates with 7.99 points have respectively a key role in investment decisions. This implies that financial variables have the greatest influence on investment decisions and political factors have a second position.

\section{Methodology}

This study is an ex post facto research which provides an empirical solution to research problems, by using data which are already in existence. Secondary data were collected from the published annual accounts of the firms for a period of ten years (2006 to 2015). The population of the study comprised the entire twenty two (22) quoted consumer goods manufacturing firms listed on the Nigeria Stock Exchange Market in 2017. A sample of six (6) firms was drawn from the twenty two (22) consumer goods manufacturing firms listed on the Nigerian Stock Exchange. The sample drawn was based on data availability and a large sample of six was selected in order to improve the accuracy of the result of the study.

The following model was developed based on the variables used in the study:

$\mathrm{PAT}=\alpha+\beta_{1} \mathrm{NCAGR}+\beta_{2} \mathrm{CAGR}+\beta_{3} \mathrm{NAGR}+\varepsilon_{\mathrm{t}}$

Where:

PAT $=$ Profit after Tax

$\alpha=$ constant

$\beta=$ Beta

NCAGR $=$ Non-Current Assets Growth Rate

CAGR $=$ Current Growth Rate

NAGR $=$ Net Assets Growth Rate

$\varepsilon_{\mathrm{t}=}$ Error or disturbance term

4. DISCUSSION OF FINDINGS

\subsection{Data Analysis}

The data collected for this study were analyzed using Pearson's Product Moment Correlation Matrix and the results presented in tables 4.7.

Table4.1. Correlations matrix of the Dependent and Independent Variables

\begin{tabular}{|l|l|l|l|l|l|}
\hline & & PAT & NCAGR & CAGR & NAGR \\
\hline \multirow{5}{*}{ PAT } & Pearson Correlation & 1 & $.255\left(^{*}\right)$ & .122 & $.580(* *)$ \\
\cline { 2 - 6 } & Sig. (2-tailed) & & .049 & .352 & C.000 \\
\cline { 2 - 6 } & $\mathrm{N}$ & 60 & 60 & 60 & 60 \\
\hline \multirow{5}{*}{ NCAGR } & Pearson Correlation & $.255\left(^{*}\right)$ & 1 & -.004 & .076 \\
\cline { 2 - 6 } & Sig. (2-tailed) & .049 & & .973 & .566 \\
\cline { 2 - 6 } & $\mathrm{N}$ & 60 & 60 & 60 & 60 \\
\hline \multirow{5}{*}{ CAGR } & Pearson Correlation & .122 & -.004 & 1 & .156 \\
\cline { 2 - 6 } & Sig. (2-tailed) & .352 & .973 & & .235 \\
\cline { 2 - 6 } & $\mathrm{N}$ & 60 & 60 & 60 & 60 \\
\cline { 2 - 6 } & Pearson Correlation & $.580(* *)$ & .076 & .156 & 1 \\
\cline { 2 - 6 } & Sig. (2-tailed) & .000 & .566 & .235 & \\
\cline { 2 - 6 } & $\mathrm{N}$ & 60 & 60 & 60 & 60 \\
\hline
\end{tabular}

* Correlation is significant at the 0.05 level (2-tailed).

Source: Author's SPSS Output

International Journal of Managerial Studies and Research (IJMSR) 


\subsection{Test of Hypotheses}

Table 4.7 presents the result of correlation analysis which was used to test the three hypotheses formulated for the study. If coefficients are replaced in the equation, the model can be defined as:

$\mathrm{PAT}=0.255 \mathrm{NCAGR}+0.122 \mathrm{CAGR}+0.580 \mathrm{NAGR}+\varepsilon$

\section{- Decision rule}

Level of significance $(\alpha)=0.05$

Reject the null hypothesis if the significant value in the Pearson Correlation Matrix is less than the level of significance (0.05), otherwise accept the null hypothesis. Based on this decision rule, the findings from the test of hypotheses are hereby presented below:

\subsubsection{Test of Hypothesis One}

There is no significant relationship between non-current assets growth rate and profit after tax of manufacturing firms in Nigeria.

- Finding: From table 4.7, the significant value of non-current assets growth rate (NCAGR) in the Pearson Correlation Matrix is 0.049 which is less than the 0.05 level of significance. Based on this, we reject the null hypothesis $\left(\mathrm{H}_{0} 1\right)$ which states that non-current assets growth rate does not significantly relate with profit after tax of manufacturing firms in Nigeria.

- Discussion of Finding One: Since the calculated value of profit after in the Person's Product Correlation Matrix is positive at 0.255 , it implies that profit after tax positively relate with noncurrent assets growth rate, this relationship is also significant at 0.049 level of significance. This implies that non-current assets growth rate of the manufacturing firms in Nigeria positively and significantly relate with the profit after tax of the companies for the period. These results are in agreement with the studies conducted by Olatunji and Adegbite (2014); Okwo, Ugwunta and Nweze ( 2012); and in disagreement with the works of Chen et al (2008) and Deloof (2003) which ended on a negative relationships.

\subsubsection{Test of Hypothesis Two}

There is no significant relationship between current assets growth rate and profit after tax of manufacturing firms in Nigeria.

- Finding: From table 4.7, the significant value of current assets growth rate (CAGR) in the Pearson Correlation Matrix is 0.352 which is greater than the 0.05 level of significance. Based on this, we accept the null hypothesis $\left(\mathrm{H}_{0} 2\right)$ which states that current assets growth rate does not significantly relate with profit after tax of manufacturing firms in Nigeria.

- Discussion of Finding Two: Since the calculated value of profit after tax in the Person's Product Correlation Matrix is positive at 0.122 , it implies that profit after tax positively relate with current assets growth rate, this relationship is, however, insignificant at 0.352 level of significance. This implies that current assets growth rate of the manufacturing firms in Nigeria positively, but insignificantly relate with the profit after tax of the companies for the period.

These results are in agreement with the studies earlier conducted by Mathuva (2009) Azam and Haider (2011), Ogundipe, Ogundipe and Ajao (2012) The study was, however, in disagreement with the findings of Duru (2014).

\subsubsection{Test of Hypothesis Three}

There is no significant relationship between net assets growth rate and profit after tax of manufacturing firms in Nigeria.

- Finding: From table 4.7, the significant value of net assets growth rate (NAGR) in the Pearson Correlation Matrix is 0.000 which is less than the 0.05 level of significance. Based on this, we reject the null hypothesis $\left(\mathrm{H}_{0} 3\right)$ which states that net assets growth rate do not significantly relate with profit after tax of consumer manufacturing firms in Nigeria. 
- Discussion of Finding Three: Since the calculated value of profit after tax in the Person's Product Correlation Matrix is positive at 0.580 , it implies that profit after tax positively relate with net assets growth rate, the level of relationship is also insignificant at 0.000 level of significance. This implies that net assets growth rate of the manufacturing firms in Nigeria positively and strongly relate with the profit after tax of the companies for the period.

This results are in agreement with the studies conducted by Farkoosh, Farkoosh \& Naseri ((2012) but disagrees with the result of the study conducted by Fairfield et al (2003).

\section{CONCLUSION}

Based on the data analysis, findings and discussions, we hereby summarize the findings as follows:

a) That non-current assets growth rate of manufacturing firms in Nigeria positively and significantly related with profit after tax of the firms.

b) That current assets growth rate of manufacturing firms in Nigeria also positively, but insignificantly related with profit after tax of the firms.

c) That net assets growth rate of manufacturing firms in Nigeria positively and strongly related with profit after tax of the firms.

In the light of the findings of this study and discussions above, we hereby conclude that non-current assets growth rate and net assets growth rate of manufacturing firms in Nigeria positively and strongly related with the profit after tax of the firms for the period of 2006 to 2015 While the current asset growth rate positively and weakly related with the profit after tax of the firms for the period. The implication of this findings and conclusion is that when the manufacturing firms' non-current assets and net assets grow, the profit after tax will also grow and vice versa. Additionally, when the current assets of the firms grows, the profit after tax will also grow, but not at the same rate as the growth in the current assets.

Based on the findings and conclusion, this study hereby recommend as follows:

a) That manufacturing firms in Nigeria should invest more money on long term projects that requires heavy investment in non-current assets. Aggressive investment in non-current intensive projects will no doubt improve the revenue generation capacity of the firms. This will also increase the profitability of the firms and will in the long run maximize shareholders' wealth.

b) Since the net assets of the firms are positively and strongly related with the profit after tax of the firms, this study further recommends that the manufacturing firms in Nigeria should increase their net asset value by increasing their total assets and reducing the components of their current liability through effective working capital and liquidity management. This will ensure that the companies are liquid while maximizing profit and shareholders' value.

c) Finally, this study in the light of the finding also recommends that the firms should increase their current assets, but should keep it at an optimum level that will ensure that maturing short-term business obligations are met and at the same time avoid keeping excess idle funds. This is because excessive increase in current assets does not result in a proportionate increase in profit after tax of the Nigeria manufacturing firms. Therefore excessive liquidity should be avoided.

\section{REFERENCES}

[1] Afza, T., and Nazir, M. (2009). Impact of aggressive asset management policy on firms' profitability. The IUP Journal of Applied Finance, 15(8), 20-30.

[2] Alchian, A. (1950). Uncertainty, evolution, and economic theory. The Journal of Political Economy, 58, 211-221.

[3] Alshubiri, E.N. (2011). The effect of working capital practices on risk management Evidence from Jordan", Global Journal of business research, 5, (1), 39-54.

[4] Amato, L. H., \& Burson, T. E. (2007). The Effects of firm size on profit rates in the financial services. Journal of Economics and Economic Education Research, 8(1), 67-81.

[5] Athar I, and Madhu M (2012). The relationship between Non-current Assets \& Firms Profitability. A publication of University, Karachi Pakistan. 
[6] Audretsch D.B. and Elston J.A. (2002) Does firm size matter? Evidence on the impact of liquidity constraints on firm investment behavior in Germany, International Journal of Industrial Organization, 20 (1), 1-17.

[7] Azam M, Haider S.I (2011). Impact of Working Capital Management on Firms' Performance: Evidence from Non-Financial Institutions of KSE. Interdisciplinary Journal Of Contemporary Research In Business, $5(3)$.

[8] Barron, D. N., West, E., \& Hannan, M. T. (1994). A Time to Grow and a Time to Die: Growth and Mortality of Credit Unions in New York, 1914-1990. American Journal of Sociology, 100(2), 381-421.

[9] Becchetti L. and Trovato G. (2002). The determinants of growth for small and medium sized firms: the role of the availability of external finance, Small Business Economics, 19 (4), 291-306.

[10] Becker-Blease, J. R., Kaen, T. K, Eteban, A. \& Bauman, H. (2010). Employees, firm size an profitability in U.S manufacturing industries. Investment Management and Finance Innovation Journal, 7(2), 7-23.

[11] Carpenter, R.E. and Petersen, B.C. (2002). "Is the Growth of Small Firms Constrained by Internal Finance?", Review of Economics and Statistics. 82(2), 298-309.

[12] Chen S. Y, Yao T, and Zhang T (2008). The effect of Asset Growth and Stock Returns in the Pacific-Basin Markets. Publication of College of Business Administration, University of Rhode Island and Eller College of Management, University of Arizona.

[13] Chiou. J.R, Cheng L and Wu.H.M(2006). The determinants of working Capital Management. Journal of America Academy of Business 10(1), 149-155.

[14] Coad, A. (2009). The Growth of Firms: A Survey of Theories and Empirical Evidence; Edward Elgar Publishing Limited: Northhampton, MA, USA.

[15] Coad, A. (2007). Testing the principle of "growth of the fitter": The relationship between profit and firm growth. Struct. Change Econ. Dyn. 2007, 18, 370-386.

[16] Davidsson, P., Steffens, P., and Fitzsimmons, J. (2009). Growing Profitable or Growing from Profit: Putting the horse in front of the Cart? Journal of Business Venturing, 24(4): 388 - 406

[17] Davidsson, P., \& Wiklund, J. (2000). Conceptual and Empirical Challenges in the Study of Firm Growth. In Sexton, D. and Landström, H. (Eds.), The Blackwell Handbook of Entrepreneurship 5(2), 26-44). Oxford, MA: Blackwell.

[18] Delmar, F. (1997): Measuring growth: Methodological considerations and empirical results," In

[19] Entrepreneurship and SME Research: On its Way to the Next Millennium, ed. by R. Donckels, and A. Miettinen, 199-216. Aldershot, VA: Avebury.

[20] Delmar, F. and Davidsson, P. and Gartner, W. (2003) Arriving at the high growth firm. Journal of Business Venturing 18(2):pp. 189-216.

[21] Deloof, M. (2003). Does asset management affect profitability of Belgian firms? Journal of Business Finance \& Accounting, 30(3-4), 573-588.

[22] Duru, A N (2014). Impact of Working Capital Management on Corporate Profitability of Nigerian Manufacturing Firms: 2000 to 2011. PHD Thesis, submitted to the Department of Accountancy, University of Nigeria.

[23] Ebrahim, M.A, Abdullah, K.A and Faudziah, H.B (2014). The Measurement of Performance's Dimension. Asian Journal of Finance and Accounting, 6(1), 24-49.

[24] Emekekwue P. (1990), Corporate Finance Management. Enugu: Otuson Nigeria Ltd

[25] Fairfield, P., J. S. Whisenant and T. L. Yohn (2003) "Accrued Earnings and Growth: Implications for Future Profitability and Market Mis-pricing," The Accounting Review, 78(1), 353-371.

[26] Farkoosh P. D, Farkoosh B.D and Naseri J (2012). The effect net assets value in purchasing the shares of investment companies. Journal Of Humanities And Social Science 2(5), 17-20, www.Iosrjournals. Org

[27] Filbeck G. \& Thomas M.K. (2005), “An Analysis of Working Capital Management Results Across Industries", Mid-American Journal Of Business, 2(20), 11-18.

[28] Goddard, J.; Molyneux, P.; Wilson, J.O.S. (2004). Dynamics of Growth and Profitability in Banking. J. Money Credit Bank. 36, 1069-1090.

[29] Goldratt E.M. (1990) What is this thing called the theory of constraints?, North River Press, Croton-onHudson, NY.

[30] Hoy, F., McDougall, P.P. and D'Souza, D.E. (1992). Strategies and Environments of High-Growth firms. In D.L. Sexton and J.D. Kasarda (eds.). The state of the art of entrepreneurship. Boston: PWS-Kent, 341357. 
[31] Jang, S.; Park, K. (2011). Inter-relationship between firm growth and profitability. Int. J. Hosp. Manag. 30, 1027-1035.

[32] Karaduman, H.A. Aknas, H.E. Caliskan, A.O. and Durer, S. (2011). The relationship between working capital management and profitability. Evidence from an Emerging market, International research Journal of Finance and Economics, 62, $61-67$.

[33] Kouser. R, Bano. T, Azeem.M , Hassan. M (2012). Inter-Relationship between Profitability, Growth and Size: A Case of Non-Financial Companies from Pakistan. Pakistan Journal of Commerce and Science, (2012), $6(2), 405-419$.

[34] Livnat J and Segal L.N (2000). The calculation of earnings per share and market value of equity: should common stock equivalent be included?

[35] Maggina A, and Tsaklanganos A (2012). Asset Growth And Firm Performance Evidence From Greece. The International Journal of Business and Finance Research 2(6).

[36] Mathuva D.M. (2009), "The Influence of Working Capital Management Components on Corporate Profitability: A Survey on Kenyan Listed Firms", Research Journal of Business Management, www.docsdrive.com/pdfs/academicjournals/rjbm/0000 /15988-15988.pdf

[37] Mukhopadhyay, A. and AmirKhalkhali, S. (2010). Profitability Performance and Firm Size- Growth Relationship. Journal of Business and Economics Research, 8(9), 121-126.

[38] Mukhopadhyay, D. (2004). Working capital management in heavy engineering firms-A case study. MANAGEMENT ACCOUNTANT-CALCUTTA-, 39, 317-323.

[39] Niresh J.A and Velnampy T(2014). Firm Size and Profitability: A Study of Listed Manufacturing Firms in Sri Lanka. International Journal of Business and Management, 4(9); 2014 ISSN 1833-3850 E-ISSN 18338119 Published by Canadian Center of Science and Education.

[40] Ogundipe.L,O. Ogundipe .S.C \& Ajao S.K (2012). Cash holding and Firm Characteristics: Evidence from Nigeria Emerging Market. Journal of Business, Economic and Finance, 1(2), 45-58.

[41] Okwo, I.M., D.O. Ugwunta and A.U. Nweze, 2012. Investment in fixed assets and firm profitability: Evidence from the Nigerian brewery industry. European Journal of Business and Management, 4(20). Available from www.iiste.org.

[42] Olatunji, $\mathrm{T}$ and Adegbite, $\mathrm{T}$ (2014). Investment in Fixed Assets and Firm Profitability: Empirical Evidence from the Nigerian Banking Sector. Asian Journal of Social Sciences and Management Studies, 1 3(1), 78-82. http://www.asianonlinejournals.com/index.php/AJSSMS

[43] Padachi, K. (2006). Trends in working capital management and its impact on firm's performance: An analysis of Mauritian small manufacturing firms. International review of business research papers. 2, (2), $45-58$.

[44] Peterson R.H (2002). Accounting for fixed assets (second edition). New York: John Wiley \& Sons, Inc.

[45] Ramezani, C. A., Soenen, L and Jung, A. (2002). "Growth, corporate profitability, and value creation", Financial Analysts Journal, 1(6), 56-67.

[46] Ramitz U. R and Junrui Z. (2014). Firm performance and emerging economics. The Journal of Apple Business Research, 30(3), 701-714.

[47] Robert K M, Mohamed S.M and Onesmus M. N (2015). Corporate size, Profitability and Market Value: An Econometric Panel Analysis of Listed Firms in Kenya. European Scientific Journal May 2015 edition 13(11), 1857 - 7881 (Print) $e$ - ISSN 1857- 7431376.

[48] Saleem, F . and Rafique, B. (2013). The determination of capital structure of oil and gas firms listed on Karachi stock exchange in Pakistan. Interdisciplinary journal of contemporary research in business. 2(9), 225-235. http://journal-archieves27.webs.com/225-235.pdf

[49] Serrasqueiro, Z. (2009). Growth and profitability in Portuguese companies: a dynamic panel data approach. Economic Interferences, 1(9), 565-573.

[50] Scott, D. L. (2003). Wall Street Words: An A to Z Guide to Investment Terms for Today's Investor. Houghton Mifflin Company.

[51] Singh, J. P., and Pandey, S. (2008). Impact of working Capital Management in the Profitability of Hindalco Industries Limited. Icfai University Journal of Financial Economics, 6(4), 62-72.

[52] Snow C. and Hrebiniak L. (1980). Strategy, distinctive competence and organizational performance. Administrative Science quarterly, 25(2), 313-336.

[53] Usama, M. (2012), Working Capital Management and its effect on Firm's Profitability and Liquidity: In other food sector of Karachi Stock Exchange (KSE). Arabian Journal of Business and Management Review, 1(12), 62-73. 
[54] Vijayakumar, A. and Devi, S.S. (2011).Growth and profitability in Indian Automobile Firms: An analysis. Journal for Bloomers of Research, 3(2), 168-177.

[55] Velnampy, T., \& Nimalathasan, B. (2010). Firm Size on Profitability: A Comparative Study of Bank of Ceylon and Commercial Bank of Ceylon Ltd in Sri Lanka. Global Journal of Management and Business Research, 10(2), 96-100.

[56] Wagenvoort R. (2003) Are finance constraints hindering the growth of SMEs in Europe?, EIB Paper, No. 7, Economic and Financial Studies, European Investment Bank.

[57] Wang, Y.J (2002), "liquidity management, operating performance, and corporate value: Evidence form Japan an Taiwan”, Journal of Multinational Financial Management, 12, 59-69

Citation: Oliver Ike, Inyiama et al. "Evaluation of the Relationship between Assets Growth Rate and Financial Performance of Manufacturing Firms in Nigeria." International Journal of Managerial Studies and Research (IJMSR), vol 5, no. 10, 2017, pp. 63-73. doi:http://dx.doi.org/10.20431/2349-0349.0510006.

Copyright: () 2017 Authors. This is an open-access article distributed under the terms of the Creative Commons Attribution License, which permits unrestricted use, distribution, and reproduction in any medium, provided the original author and source are credited. 